\title{
Van pamflet tot Fantaisie: rebelse opinievorming in de negentiende-eeuwse 'Petite Presse'
}

ARJA FIRET

In december 1851 schrijven de gebroeders Goncourt in hun dagboek het volgende over het ontstaan van het literaire tijdschrift l'Eclair, dat ze samen met hun neef Pierre-Charles de Villedeuil redigeren:

Un soir, à un café à côté du Gymnase, nous jetions par passe-temps des titres de journaux en l'air. «L'ECLAIR !» fait Pierre-Charles en riant, et continuant aे rire: «A propos, si nous fondions un journal ?». Il nous quitte, [...] imagine un frontispice où la foudre tombe sur l'Institut (...) et le dernier coup de fusil du Deux Décembre parti, l'éclair paraît. L'Institut l'avait échappé belle: la censure avait retenu le frontispice du journal. C'est le seul service que la censure nous ait rendu. ${ }^{1}$

Bovenstaand citaat zegt veel over de paradoxale situatic op het gebied van de vrijheid van meningsuiting in het negentiende-eeuwse Frankrijk. Enerzijds probeerden machthebbers de persvrijheid in te dammen. Zo slaat de genoemde datum van 2 december terug op de staatsgreep van Napoléon III, die een lange periode van strenge censuur inluidde. Anderzijds was dit een tijd waarin de pers sterk in opkomst was en de publieke opinie steeds beter bespeelde. Ondanks het gebrek aan persvrijheid, laat staan aan opinietijdschriften, slaagden vooral literaire en satirische bladen er wonderwel in om tegendraadse meningen te verkondigen. Dit gebeurde, zoals in bovengenoemde Eclair, verpakt in een literair jasje.

Het idee om op de voorpagina van L'Eclair een donderende bliksemflits op het Institut af te beelden was een heel duidelijk statement. Van een bliksemschicht op het gebouw van de Nederlandse Taalunie zou tegenwoordig niemand wakker liggen, maar het Institut de France was hét wetenschappelijke instituut van Frankrijk, dat onder meer de Académie Française herbergde. Deze prestigieuze instantie bewaakte al cen paar eeuwen lang de Franse taal en stond vooral bekend om zijn veertig 'onsterfelijke' leden die geacht wer- 
den de crème de la crème van de Franse literatuur te zijn. In werkelijkheid stond de Académie er ook toen al om bekend dat ze in het verleden juist vele literaire grootheden had gemist. ${ }^{2}$

De felle aanval van de jonge gebroeders Goncourt op het Institut is te begrijpen, wanneer je weet hoe de leden van de Académie Française aan hun plaats kwamen. Deze hadden ze over het algemeen minder te danken aan hun literaire kwaliteiten dan aan hun goede relaties met de machthebbers van de dag. In het verhaal Le Bibliomane (1831) wijst Charles Nodier erop dat deze nauwe relatie ook fysiek zichtbaar was:

[...] voilà le Pont des Arts [...], passage profondément emblématique, à la vérité, qui conduit du château (Nodier: le château royal par excellence, le Louvre) à l'Institut par un chemin qui n'est pas celui de la science. Je ne sais si je me trompe, mais l'invention de cette espèce de pont devait être pour l'érudit une révélation flagrante de la décadence des bonnes lettres. ${ }^{3}$

Hoewel de geplande 'frontispice' met de bliksemflits geen directe aanval was op de regering, wisten de negentiende-eeuwse lezers deze speldenprik aan het adres van het regime feilloos te interpreteren. Ze waren gewend aan censuur en dus ook getraind in het lezen van dit soort bedekte boodschappen. Voor een hedendaagse tijdschriftonderzoeker is dat minder gemakkelijk. Om bepaalde artikelen of verhaaltjes te kunnen interpreteren, moet je goed op de hoogte zijn van de toenmalige actualiteit. Vervolgens moet je alert zijn op bedekte parallellen en kleine, humorvolle toespelingen. Voor degene die hier handigheid in heeft gekregen, wordt al snel duidelijk dat dit soort literaire en satirische tijdschriftjes een voorzichtige, maar toch belangrijke rol speelden in het publieke debat. Hun boodschap had blijkbaar zoveel effect dat geregeld artikelen, logo's en hele tijdschriften verboden werden.

In dit artikel wil ik laten zien hoe dat gebeurde. Via de historische context zal ik iets zeggen over drie factoren die er in de negentiende eeuw voor zorgden dat de openbare opinie niet meer alleen via pamfletten, maar ook via polemische krantenstukjes bespeeld werd. Vervolgens zal ik aangeven hoe drie specifieke literair-journalistieke genres hier een belangrijke rol in speelden. Dit waren achtereenvolgens het Feuilleton, de Fysiologie en de 
Fantaisie. Op dit laatste, en meest onbekende, genre zal ik wat dieper ingaan.

\section{HISTORISCHE CONTEXT}

Satirische en polemische geschriften bestaan al heel lang. Hoe streng koningen of keizers door de eeuwen heen ook waren, er waren altijd wel auteurs die hun stem in het publieke debat durfden laten horen. Ze gebruikten daar allerlei media voor: zo schreven ze leuzen op de muur, drukten stiekem pamfletten of schreven theaterstukken die op een bedekte manier misstanden aan de kaak stelden. Maar tot het eind van de achttiende eeuw stonden deze kritische geluiden in ieder geval niet in de krant. Aanvankelijk omdat deze nog niet bestond, maar ook nadat dit nieuwe medium zich had gevestigd, keek men wel uit om minder welgevallige zaken aan de orde te stellen.

Pamfletten brachten al nieuws voordat de krant bestond, maar stonden vooral ook bekend vanwege hun bijtende commentaar op dat nieuws. Omdat machthebbers hier vaak erg benauwd voor waren, werden pamfletten al verboden sinds de 16e eeuw. Toch stonden overheden en bestuurders vaak machteloos. Het enige wat ze konden doen om ongewenst nieuws tegen te gaan, was de kranten onder strenge controle te houden via een stelsel van monopolies en privileges. Het resultaat was slechts een klein aantal officiële, zeer volgzame kranten.

Frankrijk was één van de landen in Europa waar de censuur het strengst en doeltreffendst was. Vorsten en adel hadden er absolute macht, maar ook de kerk had er een verstrekkende invloed op de publieke opinie. Tegelijkertijd was in het Frankrijk van de zeventiende en achttiende eeuw de satire alomtegenwoordig. Te denken valt aan de komedies van Molière of de fabels van La Fontaine in de zeventiende eeuw, of aan de eigenzinnige werken van Voltaire en Diderot in de achttiende eeuw. In deze vreemde situatie was commentaar op het nieuws dus streng verboden, terwijl men relatief toletant was in het domein van de literatuur.

Tot aan de negentiende eeuw had het pamflet, dat vaak eenmalig op een bepaalde gebeurtenis reageerde, een anoniem en vluchtig karakter. In de negentiende eeuw zorgden een drietal factoren in Frankrijk er echter voor dat tegendraadse opinies op veel grotere schaal en met steeds meer regelmaat geventileerd konden worden. Allereerst vormden de revoluties van 1789 , 
1830 en 1848 een directe inspiratiebron. De plotselinge volksopstanden lieten de gewone burger namelijk zien dat massaal verzet tegen strenge regimes wel degelijk effect had. Daarbij gaven deze hem de mogelijkheid heel even te ruiken aan een wat grotere persvrijheid. Met het verstrijken van de jaren leek het of burgers steeds minder bereid waren deze vrijheid nog af te staan. Een tweede factor van belang was de aanwezigheid van een groot aantal goed geschoolde en vaak provinciale jongeren in Parijs die buiten de bourgeois samenleving vielen. $\mathrm{Zij}$ waren erg ontvankelijk voor de ideeën van de revolutie, en velen zochten dan ook naar een manier waarop ze die konden uiten. De laatste factor was de ongekende opmars van wetenschap en techniek, en in het bijzonder van de nieuwe druktechnieken. Deze zorgde ervoor dat kranten en tijdschriften makkelijker, sneller, en in grotere oplages gedrukt konden worden; en dat er bovendien een steeds grotere diversiteit in de pers ontstond. Het was voor het eerst in de geschiedenis dat auteurs de mogelijkheid kregen om van de pen te leven.

De interactie tussen de opkomende pers en de door de revolutie geïnspireerde jongeren zorgde ervoor dat er - naast de officiële Grande Presse - een nieuw soort opiniërende pers opkwam. In plaats van gebruik te maken van de traditionele media, die in handen waren van de gevestigde orde, zochten de jongeren hun weg naar een eigen, non-conformistische Petite Presse. Niet zelden richtten ze ook hun eigen blad op. Hier konden ze hun eigen ideeen uiten en waren ze niet gebonden aan de conventies van de conservatieve burgerij. Integendeel, ze experimenteerden er met allerlei literaire genres en probeerden de publieke opinie op een subtiele en bedekte wijze te bespelen.

In de negentiende eeuw namen dit soort kleine rebelse bladen geleidelijk aan de rol van het pamflet over. Polemische stukjes begonnen nu dus in de krant te verschijnen. Dat is een interessant gegeven, omdat het aangeeft dat de pers een grotere onafhankelijkheid zocht, en deze blijkbaar ook vond. Het is intrigerend om te zien hoe drie literair-journalistieke genres in de pers, ieder op zijn eigen manier, hierbij een belangrijke rol hebben gespeeld: het Feuilleton, de Fysiologie en de Fantaisie. Het zijn stuk voor stuk erfgenamen van het pamflet en voorlopers van de twintigste-eeuwse column. Ze vormen een belangrijke schakel in de ontstaansgeschiedenis van opinietijdschriften. 
HET FEUILLETON

In het begin van de negentiende eeuw maakte de rebellie heel voorzichtig haar entree in de pers, via het Feuilleton. Zoals al eerder betoogd ${ }^{4}$, ging het hier niet over de smeuïge vervolgverhalen die in de jaren 1830 hun intrede deden. De term feuilleton (verkleinwoord van feuille) betekende oorspronkelijk zoiets als 'klein blaadje'. Het verwees naar het literaire gedeelte onderaan de bladzijde, dat door een dikke streep afgescheiden was van het officiële politieke bovengedeelte van de krant. Dit onderste gedeelte vormde als het ware een klein krantje op zich. Rond 1800 begon de theatercriticus en priester Julien Geoffroy dit Feuilleton vol te schrijven met grappige en scherpzinnige stukjes. Het ging aanvankelijk niet eens zozeer om de inhoud, als wel om de vorm en de esprit, en de ogenschijnlijk losse pols waarmee hij zijn observaties en kritieken schreef. Het Feuilleton was een soort literaire speeltuin die door de overheid getolereerd werd. De stukjes hadden een apolitiek karakter: ze moesten vooral levendig en grappig zijn, want ze waren bedoeld om de lezer te vermaken. Maar geleidelijk aan ontstond de vreemde situatie dat in het streng gecensureerde bovengedeelte van de krant alleen officieel politiek nieuws en wat gemengde berichten stonden, terwijl men in het Feuilleton onderaan het blad vrijwel alles kon zeggen wat men wilde. De censuur was namelijk veel milder ten opzichte van het gedeelte onder de streep. Hier konden de meest brandende politieke kwesties worden besproken onder het mom van bijvoorbeeld een verslag van een saaie tragedie.

In het begin van de negentiende eeuw was de Feuilletonrubriek dus een interessant gedeelte van de krant. Vanaf 1836 begon het Feuilleton echter duidelijk van karakter te veranderen. Van een vrijplaats waarin van alles gepubliceerd kon worden, ontwikkelde het Feuilleton zich tot een rubriek met uitsluitend populaire vervolgverhalen. Het werd daarmee dé commerciële bron van inkomsten waarop de meeste kranten draaiden. Een handige bijkomstigheid voor het strenge regime was dat dit nieuwe Feuilleton het volk in een droomwereld liet leven en hen de harde werkelijkheid, en vooral hun revolutionaire ideeën, deed vergeten.

DE FYSIOLOGIE

Aanvankelijk had men vanaf 1830 - na de revolutie en de komst van de parlementaire Juli-Monarchie van koning Louis-Philippe - genoten van een 
relatief grote vrijheid van meningsuiting. Maar de situatie was snel omgeslagen toen de satire in de pers de koning teveel werd. In 1835 werd de censuur weet in ere hersteld. Het is niet toevallig dat rond diezelfde tijd de Fysiologie de tegendraadse rol van het Feuilleton overneemt.

De meer bedekte kritiek van de Fysiologie paste goed in deze tijd van hernieuwde censuur. De schrijvers ervan richtten zich namelijk niet meer op een specifiek individu, maar op algemene types die bepaalde sociale groeperingen, beroepsgroepen of standen van de bevolking vertegenwoordigden. Zo dreven de Fysiologieën de spot met de aard van een bepaald soort mensen, zoals in de Physiologie du Fumeur (1840), Physiologie du Blagueur (1841), de Physiologie du Célibataire et de la Vieille Fille (1841). Ook buitenstaanders of personen van een specifieke sociale stand moesten het ontgelden, in bijvoorbeeld de Physiologie de l'Anglais à Paris (1841) of de Physiologie du Bourgeois (1841). Bepaalde beroepsgroepen bleken ook een dankbaar object van beschrijving, zoals blijkt uit de Physiologie de la Portière (1841), de Physiologie du Curéde campagne (1841) of de Physiologie des Employés de ministères (1862). Tenslotte waren bepaalde facetten van het Parijse leven interessant om een fysiologie aan te weiden, zoals in bijvoorbeeld de Physiologie du Gant (1841), de Physiologie des Bals de Paris (1841) of de Physiologie du Chapeau de soie et du Chapeau de feutre (1841). Er werd zelfs een Physiologie des Physiologies gepubliceerd. ${ }^{5}$

Deze manie om de maatschappij op een speelse manier onder te verdelen in alle mogelijke soorten, klassen en subtypen is uit de context van die tijd te verklaren. De term physiologie kwam oorspronkelijk uit het technische vocabulaire van wetenschappers. Vanaf ongeveer 1810 bestond er in de medische fysiologie al een grote bezetenheid om alles te classificeren en te beschrijven. De term was geleidelijk aan in de spreektaal terecht gekomen en het was niet verwonderlijk dat de Fysiologie als genre uiteindelijk zijn intrede deed in de literatuur, te beginnen met Balzacs Physiologie du mariage uit $1830 .{ }^{6}$ Maar de ware aanleiding voor de furore van het genre vormden een spotprent van Charles Philipon en een stukje van Sebastien Peytel. Philipon was niet alleen een bekende tekenaar van spotprenten, maar ook de stuwende kracht achter de satirische bladen La Caricature en Le Charivari, en achter het uitgevershuis van zijn zwager Aubert. Hij maakte een karikatuur van het gezicht van Louis-Philippe, waarin deze langzaam in een peer veranderde $(1832) .^{7}$ Hierdoor geïnspireerd schreef Peytel de Physiologie de la Poire $(1832)^{8}$, 


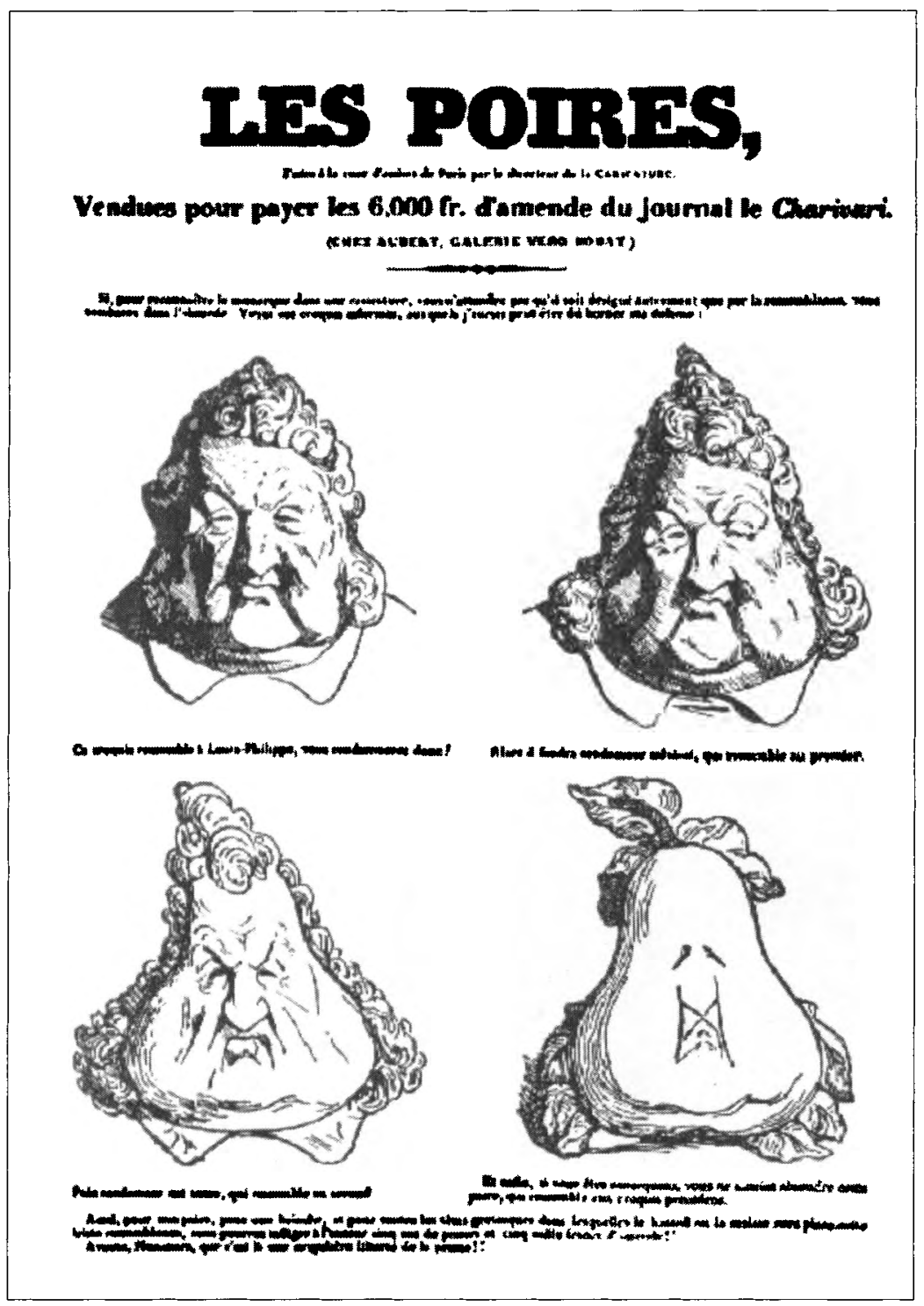

De metamorfose van koning Louis-Philippe in een peer door Charles Philipon gepubliceerd in La Caricature (26 januari 1832) 
en daarna ging de rest vanzelf. Van een serieuze natuurwetenschappelijke studiemethode ontwikkelde de Fysiologie zich tot een burlesk literair gente, dat eerder een parodie op deze classificatie-mode was.

De kleine, goedkope en herkenbare boekjes van ongeveer honderd bladzijden droegen op de voorpagina de titel Physiologie en waren voor de spotprijs van 1 franc te koop. Kenmerkend waren de grappige en humoristische toon en het grote aantal etsen die de boekjes illustreerden. De Fysiologieën verschenen tussen ongeveer 1835 en 1850 , en in de bloeitijd van 1840 tot 1842 werden de bewoners van Parijs er onder bedolven. De gemiddelde oplage van 3500 kon soms omhoog schieten naar 20.000 stuks. Eén van de redenen waarom het genre zo'n succes kende, ligt in het feit dat Aubert - één van de twee uitgevers die het monopolie op deze boekjes hadden -, tegelijkertijd ook de uitgever van de satirische bladen La Caricature en Le Charivari was?.

De nauwe relatie tussen de satirische tijdschriften van Charles Philipon en het genre van de Fysiologie ligt voor de hand. De strenge perswetten van september 1835 betekenden de ondergang van de openlijke politieke karikatuur. Het is niet verbazingwekkend dat juist Philipon, de animator van een aantal satirische bladen waar dergelijke spotprenten in werden gepubliceerd, een nieuwe uitlaatklep verzon. Voor een tijdschrift waar altijd al getekende karikaturen te bewonderen waren, was het geen grote stap om ook geschreven karikaturen op te nemen. En hoewel de kritiek in een Fysiologie veel meer gemaskeerd was, was deze nog steeds vaak verankerd in de politieke actualiteit. De Fysiologieën leken de politieke satire zelfs weer tot leven te brengen. Geïnspireerd door de typische vergroting en misvorming van karaktertrekken in de spotprenten, zetten de schrijvers van de Fysiologie deze techniek om in woorden. Niet voor niets werd dit genre door Balzac gekenschetst als een 'plaisanterie écrite à coups de crayon'.10

DE FANTAISIE

De Fantaisie volgde op haar beurt de Fysiologie weer op, en verscheen grofweg tussen 1840 en 1870 in de kolommen van de Petite Presse. Verschenen haar polemische voorgangers nog buiten de krant, of in ieder geval in het aparte feuilletongedeelte, de Fantaisie stond midden tussen de artikelen over de actualiteit. ${ }^{11}$ Deze verschuiving van het commentaar op het nieuws naar het informatieve hart van het blad boven de zwarte streep was een be- 
langrijke stap in de ontwikkeling naar meer vrijheid van meningsuiting in de pers.

De Fantaisie was een soort column avant la lettre die, ondanks zijn plaats in het bovengedeelte van het blad, wel een aparte rubriek vormde te midden van de nieuwsartikelen. De stukjes onderscheidden zich vaak door hun lettertype of vormgeving, of door het kopje Fantaisie. Wie zijn prozaschets een Fantaisie noemde, gaf daarmee te kennen dat hij een spontane inval noteerde of een momentopname van iets gaf, zonder zich te bekommeren om de literaire conventies. In negentiende-eeuwse woordenboeken vinden we deze betekenissen van de term fantaisie: 'originele verbeeldingskracht', 'plotselinge opwelling', 'persoonlijke vrijheid', en als deze ver doorgevoerd werd ook 'opstand', in de betekenis van 'je sterk afzetten tegen de maatschappij'. Deze connotaties herkende de lezer ook duidelijk in de literaire Fantaisie: de schrijver was er vrij om te schrijven wat hij wilde, en het genre leek hooguit als regel te hebben dat het geen regels had. Het gevolg was dat een Fantaisie alle vormen, stijlen en soorten inhoud kon bevatten.

De geboorte van het genre van de Fantaisie was, net als die van het Feuilleton en de Fysiologie, een antwoord op de specifieke situatie van die tijd. Hoewel de eerste stukjes in de relatief vrije jaren rond 1830 verschenen, begon de productie te bloeien in de jaren 1840 en bereikte die zijn absolute hoogtepunt in de jaren 1850 en 1860 . De blocitijd van het genre viel samen met één van de meest rigide regimes van de negentiende eeuw: het Tweede Keizerrijk van Napoléon III. In deze tijd van strenge censuur werden soms wel 60 Fantaisies per jaar gepubliceerd. De meeste verschenen in bladen als Le Figaro, L'Eclair, Paris, L'Artiste en La Revue de Paris; en begin jaren 1860 ook in La Revue Fantaisiste en Le Soleil.

Het idee om een stukje in een krant of tijdschrift als Fantaisie aan te duiden bleek een geweldige vondst. Achter de façade van deze titel verwachtte de negentiende-eeuwse lezer namelijk geen serieuze beschrijving van de maatschappij. Juist daardoor konden de Fantaisies gemakkelijk worden gepubliceerd in een pers, die verder volledig werd beheerst door de censuur. Het aardige was dat de titel in de praktijk niet alleen als dekmantel, maar ook als uithangbord werd gebruikt. Enerzijds leek de titel een vrijbrief om van alles te kunnen zeggen. Anderzijds gaven de Fantaisistes met hun keuze voor deze titel bewust een tegendraads signaal af. In een tijd dat traditie en 
imitatie van grote schrijvers nog steeds de norm waren, stond de betekenis van het woord fantaisie immers lijnrecht tegenover de waarden van de conservatieve bourgeois. Deze combinatie van behoedzame voorzichtigheid en openlijke subversiviteit is karakteristiek voor het genre.

In mijn corpus is het aantal stukjes dat openlijk aan de actuele politiek refereert zeer klein. Deze uitzonderingen op de regel verschenen in een tijd van relatieve persvrijheid, tussen 1830 en 1832 . In tegenstelling tot de latere Fantaisies, durfde men hier nog openlijk in te gaan tegen de koning en de censuur. Deze vroege Fantaisies stonden in La Caricature, gebroederlijk naast de beschreven perenspotprenten van Louis-Philippe, maar ze verdwenen na mei 1832; mogelijk werden ze toen al gevaarlijk geacht. In augustus 1835 ging La Caricature zelf ten onder door de herinvoering van de censuur. Toen het een doorstart maakte als Le Charivari, was dit blad duidelijk meer op zijn hoede: de auteurs ondertekenden hun stukjes niet meer.

In de hieropvolgende periode verdwenen alle openlijke verwijzingen naar koning, keizer, politiek of censuur als sneeuw voor de zon. Dat wilde niet zeggen dat de Fantaisies hun rebelse karakter hadden verloren: de revolutie van 1848 zorgde er tussendoor nog voor dat de drang naar een grotere vrijheid van meningsuiting springlevend was. Maar de spot drijven met $\mathrm{Na}-$ poleon III, zoals dat in de jaren 1830 werd gedaan met 'Lolo-Phiphi', was niet meer mogelijk. De auteurs waren gedwongen hun rebellie op een veel subtielere manier aan hun lezers duidelijk te maken. Het werd een ware kunst om je eigenzinnige mening in een zo fantasierijke vorm te verpakken, dat deze enerzijds niet in het oog sprong van de censuur, maar anderzijds de lezers wel wist wakker te schudden. Hiervoor werden tal van literaire vormen en technieken ingezet.

Allereerst verhulden veel schrijvers van Fantaisies hun identiteit, net als vroeger de pamfletschrijvers. Maar liefst 311 van de 724 Fantaisies die ik heb gevonden, zijn niet, of alleen met een schuilnaam, ondertekend. Deze pseudoniemen liepen uiteen van geheimzinnige initialen en anagrammen tot potsierlijke vondsten als 'TOUCHE-À-TOUT' of 'PARAFARAGARAMUs' of omschrijvingen als 'Un comète qui a perdu sa queue' of 'Un de vos lecteurs à beau nez'. Vooral de Figaro, Le Hanneton, La Lune en Le Tintamarre blonken uit in het verzinnen van dit soort bizarre namen.

Daarnaast was het veel veiliger om kritiek op de machthebbers te verhul- 
len in een fantasierijke literaire vorm. Zo kon een Fantaisie de vorm aannemen van een sprookje, een brief, een essay, een reisverslag, een boekbespreking, een dialoog, een allegorie, een persiflage, een fysiologie, een serieus verhaal of een satirisch epigram; vormen die je vandaag de dag nog steeds tegenkomt in columns. Tegen beschuldigingen die wezen op een gelijkenis met reële personen of gebeurtenissen, kon men zich gemakkelijk verdedigen door te wijzen op het fictionele karakter van de tekst.

Ook in de inhoud van de Fantaisie zie je steeds een bedekte vorm van rebellie terugkeren. Zo gaven de stukjes een duidelijk statement af door figuren ten tonele te laten verschijnen die een marginale plek in de maatschappij innamen. Deze personages hadden er, net als de auteurs zelf, voor gekozen om vrij en onafhankelijk te zijn, maar betaalden daarvoor wel de prijs van de armoede. Er verschijnen opvallend veel boeken over excentrieke en marginale schrijvers en personen uit de negentiende eeuw of daarvoor. ${ }^{12}$ Het is overduidelijk dat de auteurs ervan zeer geïnspireerd waren door deze markante persoonlijkheden. Daarnaast duiken veel beschrijvingen op van de jonge bohémiens in Parijs die sterke kritiek hadden op de traditionele burgerlijke levenswijze. Naast wat losse Fantaisies over deze vie bohémienne, verschenen er verschillende bundels die samen een mooi beeld geven van de evolutie van deze levensstijl. Was de zogenoemde 'Bohème dorée' in de tijd van Théophile Gautier, Gérard de Nerval en Arsène Houssaye rond 1830 nog behoorlijk dromerig en romantisch; de Bohème van Henri Murger en Champfleury rond 1848 was al heel wat scherper en realistischer; terwijl deze echt wrang en naturalistisch werd in de tijd van Jules Vallès. ${ }^{13}$ De Fantaisies werden ook regelmatig bevolkt door straatfiguren, artiesten of 'saltimbanques'. Allen zijn straatarm, maar vrij om te doen en laten wat ze willen. Geheel in deze lijn droegen sommige tijdschriften titels die aan deze leefomstandigheden refereerden: Le Sans-le-Sou (1854-1855), Le Bohême (1855-1856), Le Bohémien (18551856), La Bohême (1865-1866) en La Mansarde (1856).

In veel Fantaisies werden fictieve of historische personen ingezet om kritiek te leveren op de maatschappij. Zo wordt het negentiende-eeuwse Parijs door Cervantes' Don Quichotte onder de loep genomen ${ }^{14}$, en ook de Griekse schrijver Aristophanes zien we naar Parijs komen om de absurditeit van de negentiende-eeuwse maatschappij te ontdekken. ${ }^{15}$ Dit soort romanfiguren en auteurs zien we ook terug in de titels van een aantal feuilles fantaisistes, zoals 
Le Diable Boiteux (1857) ${ }^{16}$, de Figaro (1e serie: $\left.1854^{-1866}\right)^{17}$ of de Rabelais (1857). Alphonse Daudet laat sprookjesfiguren als Roodkapje ${ }^{18}$ en Blauwbaard ${ }^{19}$ kritisch uit de hoek komen in een eigentijdse setting. Théophile Gautier laat in zijn Fantaisie 'Mille et deuxième Nuit. Fantaisie de couleur orientale' het personage Sheherazade's avonds bij de schrijver aankloppen voor raad. De sultan wordt hier vergeleken met het publiek van Gautier: dat is ook nooit tevreden. En hoewel de lezers de schrijver niet vermoorden, vergeten ze hem gewoon, wat volgens de ik-persoon nog etger is. ${ }^{20}$ Maar ook buitenlanders zijn heel geschikt om met kinderlijke onschuld kritische uitspraken te doen over de negentiende-eeuwse maatschappij ${ }^{21}$. Tenslotte spelen ook dieren of dingen een belangrijke rol in de Fantaisie. Of het nu gaat om de nachtegalen van Gautier of Daudet ${ }^{22}$, de kuiten van Parijse dames ${ }^{23}$, de pratende kunstgebitten van de gebroeders Goncourt ${ }^{24}$ of de tot leven komende boeken van de Bibliothèque Nationale ${ }^{25}$ : de toespelingen die ze maken op de negentiende-eeuwse tijdgenoten zijn kritischer dan een persoon ze ooit had kunnen maken.

Schrijvers kozen cr ook vaak voor om een fictieve wereld te schetsen. Door verhaaltjes in het buitenland, in een vroegere maatschappij of in een gefingeerd land te situeren, was een auteur minder snel op maatschappijkritiek te betrappen. Zo zijn de Promenades sentimentales dans Londres et le Palais de Cristal (1851) een luchtige reeks reisindrukken die Jules de Prémaray opdoet tijdens zijn reis in Londen. ${ }^{26}$ Hoewel de hoofdpersoon zeer satirisch is over de hoofdstad en haar inwoners, blijkt de Engelse maatschappij bij terugkomst nog niet zo slecht vergeleken met de Franse. Een aardig bijkomend detail is dat het hier gaat om het eerste deel van de serie Bibliothèque de la Fantaisie die bij de uitgevers D. Giraud et J. Dagneau uitkwam. In een andere Fantaisie laat Alphonse Daudet een aantal bewoners van een gekkenhuis functioneren als normale mensen. In deze omgekeerde wereld vinden de gekken, die zich niet toevallig Fantaisistes noemen, zichzelf helemaal niet gek en kwalificeren de buitenwereld juist als fou. ${ }^{27}$ In het toneelstuk L'imagier de Harlem ou la Découverte de l'imprimerie (1852) van Nerval en Méry ligt de parallel tussen de uitvinding van de boekdrukkunst en de revolutionaire ontwikkelingen in de negentiende-eeuwse pers voor de hand. ${ }^{28}$ De duivel, waartegen uitvinder Laurent Coster zich uit alle macht moet verdedigen, staat symbool voor de strenge wetten van 1850 die de pers aan banden legden. De Histoire du 
Roi de Bohême et de ses sept châteaux (1830) en de Fantaisies du dériseur sensé (1853) van Charles Nodier lijken van alle Fantaisies nog het meest bizar. ${ }^{29}$ In het eerstgenoemde verhaal is zelfs niet eens een gefingeerde wereld terug te vinden, zo absurd is deze onsamenhangende verzameling fragmenten die over alles gaat, behalve over de 'Roi de Bohême'.

Hoewel de Fantaisies in de ogen van een hedendaagse lezer mogelijk onschuldig aandoen, moet hij zich niet vergissen in de moed die er nodig was om dit soort stukjes te schrijven. Het was de tijd waarin Gustave Flaubert voor de rechter kwam vanwege vermeende immoraliteit van Madame Bovary, en waarin Baudelaire asiel moest zoeken in Brussel. In een cultuur die zo beheerst werd door de censuur, moeten de Fantaisies wel degelijk effect hebben gehad. Maar veel expliciet bewijs is er helaas niet voor. Wel is geregeld in de bladen te zien dat artikelen of spotprenten niet door de censuur zijn gekomen: bij wijze van protest blijft de plek waar deze hadden moeten verschijnen, dan maagdelijk wit. Vaak worden ook hele tijdschriften door de censuur verboden. Interessant zijn de sporadische lezersbrieven en redactionele stukjes, die getuigen van het effect van een blad op de lezers. In juni 1863 meldde het blad Le Hanneton bijvoorbeeld dat ze hun bijna 'bloeddorstig wrede' serie over de Villemessant - de bekende hoofdredacteur van de Figaro - zouden opschorten, omdat de 83 reacties die ze van de lezers ontvingen echt te ver gingen. ${ }^{30}$ Tenslotte is ook in een bundel van Charles Monselet een noot te lezen over het feit dat, in de tijd tussen zijn artikelen over de Bibliothèque Nationale in de Figaro en hun verschijning in deze bundel, men in deze Bibliotheek veranderingen had doorgevoerd. ${ }^{31}$

Het effect van de Fantaisie is vooral af te lezen aan de verschillende querelles fantaisistes. Eén van deze literaire twisten ontstaat naar aanleiding van een zeer aanvallende Fantaisie van de gebroeders Goncourt in L'Eclair. Dit stukje had hetzelfde effect als het door de censuur verboden titelvignet, met het verschil dat het niet in getekende, maar in geschreven vorm verscheen. In het verhaal krijgt een klein meisje, dat 'toevalligerwijs' ook de naam Fantaisie draagt, een pak slaag op de billen van de bekende hoogleraar Saint Marc de Girardin. Dit was geen willekeurig mikpunt: naast zijn functie als hoogleraar aan de Sorbonne, was de Girardin lid van de Académie Française. Daarbij was hij één van de bekendste redacteuren van het Journal des Débats - een officiële staatskrant - en bovendien parlementariër, staatssecretaris en 
minister van onderwijs. Een aanval op Saint Marc de Girardin stond dus gelijk aan een aanval op de officiële literatuur en op de staat. Het grote aantal artikelen dat in februari en maart 1852 op deze kwestie reageert en een duit in het zakje doet, geeft aan dat dit soort Fantaisies wel degelijk werden gelezen en de gemoederen beroerden.

Ondanks de precaire situatie op het gebied van de vrijheid van meningsuiting slaagden de drie eigenzinnige genres van het Feuilleton, de Fysiologie en de Fantaisie er dus in om de Franse publieke opinie te bespelen. Dat kwam voor een niet onbelangrijk deel door hun literaire vorm. Het was voor het eerst dat polemische stukjes een plek in de pers wisten te veroveren, waardoor subversieve meningen met meer regelmaat en op grotere schaal konden worden geventileerd. In die zin vormen deze drie literair-journalistieke genres een belangrijke schakel in de ontstaansgeschiedenis van de hedendaagse column of opinietijdschriften. De noodzaak om je mening per definitie in een literair jasje te verhullen, leek af te nemen naarmate de machthebbers democratischer werden. Na de volksopstand van de Commune in Parijs en het aantreden van de Derde Republiek in 1871, kwam de Fantaisie nog maar sporadisch voor. Er verschenen voornamelijk nog bundels met stukken die al eerder waren uitgekomen. De tijd was duidelijk rijp voor meer openlijke vormen van debat.

> ARJA FIRET werkt aan een proefschrift over het literair-journalistieke genre van de Fantaisie. Daamaast is zij vakspecialist Romaanse letterkunde bij de Universiteitsbibliotheek van de Universiteit Utrecht.

1. 'Op een avond, in een café naast de gymzaal, riepen we als tijdverdrijf zomaar in het wilde weg wat titels van kranten. «L'EC LAIR] [De B LIKSEMFLITs!)" zei Pierre-Charles lachend, en tenwijl hij bleeflachen [zei hij]: «tussen twee haakjes, als wij nu eens blad oprichtten?). Hij verliet ons [...], bedacht een logo/titelplaat waar een bliksemflits precies op het Institut neerkomt [...], en zodra het laatste geweerschot van 2 december was uitgedoofd, verscheen het blad L'ECLAIR. Het Institut had geluk en was maar 
ternauwemood ontsnapt: de censuur had het logo van het blad tegengehouden. Dat is de enige dienst die de censuur ons ooit bewezen heeft.' Edmond en Jules de Goncourt, Journal, mémoires de la vie littéraire, Vol. 1: 1851-1865. Paris: Robert Laffont, 1989,

$$
\text { p. } 31 \text {. }
$$

2. In 1856 schrijft Arsène Houssaye het hilarische Histoire du 41 me fauteuil de l'Académie Française. Het is het verhaal van wat de Académie Française had kunnen zijn, als ze een groot aantal bekende schrijvers in haar midden had gekozen.

3. '[...] ziedaar de Pont des Arts [...], om eerlijk te zijn, een uiterst symbolische overgang, die van het paleis (noot Nodier: 'het koninklijk paleis bij uitstek, het Louvre') naar het Institut loopt, via een pad dat niet die van de wetenschap is. Ik weet niet of ik me vergis, maar het bedenken van dit soort bruggen zou voor de geletterde een overduidelijke onthulling moeten zijn van het verval van de schone letteren.' Charles Nodier, 'Le Bibliomane', in Contes. Paris: Garnier, 1983 , p. 507.

4. Zie Arja Firet, 'Literatuur in de marge: van Feuilleton tot Fantaisie in negentiendeeeuwse Franse kranten en tijdschriften.' Ts.>Tijdschrift voor tijdschriftstudies 17, 2005, p. 29-41.

5. Voor een volledige lijst van Physiologies, zie: 'Répertoire des Physiologies', in Andrée Lhéritier, Les Physiologies. Catalogue des collections de la Bibliothèque Nationale. (Établi et présenté par Andrée Lhéritier). Paris: Université de Paris, Institut français de Presse, 1957, p. 13-58.

6. Honoré de Balzac, Physiologie du mariage ou Méditations de philosophie éclectique sur le bonheur et le malheur conjugal publiées par un jeune célibataire. Paris: Levavasseur, 1830.

7. Charles Philipon, in: La Caricature, 26 januari 1832 .

8. Sébastien Peytel, Physiologie de la poire, par Louis Benoît, jardinier. Paris: chez les libraires de la place de la Bourse, 1832.

9. De andere uitgever was Desloges.

1o. Honoré de Balzac, Monographie de la presse parisienne. Paris: Arléa-poche, 1998 [1843], P.

113.

11. Bij de Fantaisie is de overgang mooi te zien: sommige werden nog in het onderste gedeelte van het blad gepubliceerd, maar de meeste verschenen boven de lijn en verschilden nauwelijks van de artikelen eromheen. 12. Zie o.a. Théophile Gautier, Les Grotesques (1844); Champfleury, Les Excentriques (1852); Gérard de Nerval, Les Illuminés (1852); Charles Monselet, Les oubliés et les dédaignés (1857); Jules Vallès, Les Réfractaires (1866); Edmond et Jules de Goncourt, Quelques créatures de ce temps (1876).

13. Zie Théophile Gautier, Les Jeunes-France. Romans goguenards (1833); Henri Murger, Scènes de la vie de Bohême (1851); Champfleury, Les Aventures de mademoiselle Mariette (1857); Jules Vallès, Les Réfractaires (1866).

14. Zie de verschillende Fantaisies van Léon Gozlan over Don Quichotte en Sancho in Parijs, die in La Chronique Parisienne verschenen (oktober-november 1858 ).

15. Théodore de Banville; Philoxène Boyer, 'Le feuilleton d'Aristophane. Comédie satirique', in: Comédies. Paris: Michel Lévy, 1853. 
16. Dit verwijst naar het manke duiveltje uit Le Diable Boitewx van Alain-René LeSage (1707), die door daken en muren heen kon zien en op subtiele wijze de mensen een spiegel voorhield van hun tekortkomingen. Op zijn beurt had LeSage dit personage overgenomen van El Díablo conjuelo van Luiz Velez de Guevara (1641). Heel aardig is dat dit Franse blad ook een tegenhanger had in de gelijknamige Nederlandse lilliputter Asmodée (1854-1911).

17. De satirische kapper van Le Barbier de Séville (1775) en Le Mariage du Figaro (1784) van Pierre de Beaumarchais.

18. Alphonse Daudet, 'Le Roman du Chaperon Rouge'. Le Figaro, 18 december 1859 , p. 2-4.

19. Alphonse Daudet, 'Les huit pendus de Barbe-Bleue. Moralité'. La Revue Fantaisiste, 1 juni 1861, P. 97-111.

2o. Gautier, Théophile, 'La Mille et deuxième Nuit. Fantaisie de couleur orientale.' Musée des familles, augustus 1842, p. 321-330.

21. Zie o.a. Le comte Charles de Villedeuil, Paris à l'envers (1853).

22. Théophile Gautier, 'Fantaisies. Le nid des rossignols.' Le Soleil, 28 november 1865 , p. 2 en 29 november 1865, p. 2; Alphonse Daudet, 'Les tossignols du cimetière. Fantaisie en deuil.' Le Figaro, 4 oktober 1860, p. 4-5. 23. Cornelius Holff $(=$ Villedeuil, Le Comte de), 'Mollets.' Paris, 24 oktober 1852, p. 1. 24. Zie de verschillende Fantaisies van Edmond en Jules de Goncourt, getiteld
'Histoire d'un râtelier.' Paris, oktober 1852

- januari 1853.

25. Charles Monselet, "Théâtre du Figaro.

IV. La Bibliothèque en vacances.' Le Figaro, 13 september 1857, p. 1-3; 'Théâtre du Figaro. xvir. La Bibliothèque.' Le Figaro, 21 maart 1858, p. 4-7; 'Théâtre du Figaro. XxIv. Second voyage à la Bibliothèque.' Le Figaro, 15 juli 1858 , p. 3-5.

26. Jules de Prémaray, Promenades sentimentales dans Londres et le Palais de Cristal. Paris:

D. Giraud et J. Dagneau, Bibliothèque de Fantaisie, 1851.

27. Alphonse Daudet, 'Un concours pour Charenton.' Le Figaro, 16 augustus 1860, p.

1-3.

28. Joseph Méry; Gérard de Nerval, L'Imagier de Harlem ou la Découverte de l'imprimerie. Dramelégende en 5 actes et 11 tableaux. Paris: Librairie théâtrale, 1852 .

29. Charles Nodier, Histoire du Roi de Bohème et de ses sept chateaux. Paris: Delangle frères, 1830; Charles Nodier, Les Fantaisies du Dériseur sensé ('Hurlubleu', 'Léviathan le Long', 'Zérothoctro-Schah', 'Voyage pittoresque et industriel'). Paris: Charpentier, 1853.

30. Zie het redactionele 'Avis' van het blad Le Hanneton, 21 juni 1863, p. 1 .

31. Charles Monselet, "Théâtre du Figaro. XVII. La Bibliothèque.' Le Figaro, 21 maart 1858, p. 4-7. Later gebundeld in Les Tréteaux de Charles Monselet. Paris: Poulet-Malassis et de Broise, 1859 . 